\title{
Golden Apple Snail Shell (Pomacea canaliculata) as Prospective Agent in Absorbing Lead (pb) in Water
}

\author{
Patricia Leslie Juneva E. Basigsig*, John Edward E. Makiling, Chris Jasmine T. Niog, \\ Nicole B. Sarmiento, Shirlamaine Irina G. Masangcay
}

Senior High School Department, Caraga State University, Butuan, Philippines

Email address:

trishbasigsig12@gmail.com (P. L. J. E. Basigsig)

${ }^{*}$ Corresponding author

\section{To cite this article:}

Patricia Leslie Juneva E. Basigsig, John Edward E. Makiling, Chris Jasmine T. Niog, Nicole B. Sarmiento, Shirlamaine Irina G. Masangcay. Golden Apple Snail Shell (Pomacea canaliculata) as Prospective Agent in Absorbing Lead (pb) in Water. Modern Chemistry.

Vol. 7, No. 1, 2019, pp. 1-4. doi: 10.11648/j.mc.20190701.11

Received: December 17, 2018; Accepted: January 2, 2019; Published: January 28, 2019

\begin{abstract}
Heavy metals such as cadmium $(\mathrm{Cd})$, chromium $(\mathrm{Cr})$, lead $(\mathrm{Pb})$, and mercury $(\mathrm{Hg})$ are considered to be highly intoxicating pollutants in water. This is a primary concern for developed countries like the Philippines since it creates a substantial impact on the environment and health. Absorption of these heavy metals has only been of limited use because it undergoes methods which are expensive. This research focuses on determining the probability of Golden Apple Snail (GAS) shells (Pomacea canaliculata) as a cost-effective treatment in absorbing heavy metal Lead ( $\mathrm{Pb}$ ) in water. A new chelating agent has been prepared by pulverizing GAS shells and weighing them as $20 \mathrm{~g}$ per treatment, two factors are observed in the study: agitation time of 6,12 and 18 hours and varying concentrations of 50,100, and $150 \mathrm{ppm}$. The absorptive capacity of the bioabsorbent was measured and quantified using the Flame Atomic Absorption Spectroscopy (FLAAS) as well as the residue of the Lead $(\mathrm{Pb})$ in the solution. The result of the analysis shows that the absorptive capacity of GAS shells are at $99.86 \%$ with the absorption capacity in regards of concentration are at $99.97 \%$ and with agitation time $99.96 \%$. Furthermore, results show that Sample Ca2, having 50 ppm concentration being treated for 18 hours rendered a $100 \%$ absorption of the heavy metal in the solution. It can, therefore, be concluded that GAS shell is a promising chelating agent in absorbing Lead $(\mathrm{Pb})$.
\end{abstract}

Keywords: Agitation, Atomic Absorption Spectroscopy, Bio-absorbent, Chelating Agent, Lead Concentration

\section{Introduction}

Highly intoxicating pollutants like cadmium, chromium, lead, and mercury is amongst the most alarming concerns especially with developing countries like the Philippines since they create a substantial impact on the environment and health [10].

Heavy metal pollution occurs in many industrial wastewaters such as those produced by metal plating facilities, mining operations, battery manufacturing processes, the production of paint and pigments and the glass production industry [11]. The wastewater then, if polluted by heavy metals can cause direct toxicity; not just to humans and the environment, but also to other living organisms due to their presence past specified limits [13].

Lead $(\mathrm{Pb})$, specifically, is one of the most common contaminants on the environment for its extensive use in several industries such as petroleum, mining, paint, ceramics and weapons industries. The lead build-up in the human body can cause to severe health problems such as brain damage, kidney failure, and significant developmental, learning and behavioral problems in children [6]. Lead $(\mathrm{Pb})$ is highly toxic in nature even in small amounts could cause health concerns to humans [17]. Toxicity has been shown to occur at concentrations as low as $1 \mathrm{pM}$ making significant reductions to the allowable levels of lead in drinking and irrigation waters in most countries [21].

With this, the dread of disposing heavy metals on bodies of water has also turned rampant and is now a primary concern all over the globe. Industries such as in our status quo, discharge various heavy metals such as Cadmium (Cd), Zinc $(\mathrm{Zn})$, Copper $(\mathrm{Cu})$, Chromium $(\mathrm{Cr})$, Mercury $(\mathrm{Hg})$ and Lead $(\mathrm{Pb})$. In which the mentioned metals can cause detrimental effects on our environment, especially on bodies of water 
where they are [19]. Former Secretary of the Department of Environment and Natural Resources of the Philippines, Gina Lopez, accused 28 of the country's 41 mining companies which contaminated the rivers, rice fields and watersheds with nickel laterite [1]. Considering the aftermath of disposing of heavy metals particularly lead in various bodies of water, it can brutally pollute the primary source of potable drinking water. In which if that happens, can highly contribute to the long list of environmental problems today [19].

In most cases, heavy metal traces can be found in wastewaters in the mining industry since water is used to extract minerals like coal and iron, liquids like petroleum and natural gases [5]. After such process, a minor part of the heavy metals will end up in wastewaters from the further processes of the metals. From the eco-toxicological point of view, the most dangerous metals are mercury, lead, cadmium, and chromium (VI). In which all of the heavy metals mentioned are the most common elements in wastewaters from mining companies [2].

Techniques presently in existence for removal of heavy metals from contaminated water like wastewaters include; reverse osmosis, electrodialysis, ion exchange, chemical precipitation, phytoremediation, membrane separation, and adsorption [7]. However, all the methods mentioned still has disadvantages like incomplete metal removal, high reagent, and energy requirements generation of toxic sludge or other waste products that require careful disposal [3]. With increasing environmental awareness and legal restraints being enforced on the discharge of wastes, the need for costeffective alternative technologist are essential. In this endeavor, absorption has emerged as a superior to mother techniques because of its capability of absorbing a broad range of different types of absorbents efficiently [8].

Absorption of heavy metal ions is an efficient and wellestablished method for their removal from intoxicated water. However, it does not come off cheap therefore limiting its widespread use all around the globe since not everybody can easily afford it. Thus, studies have been made in hopes to formulate an absorbent that is significantly similar in efficacy and yet is cheaper in monetary value [18]. According to Araujo, Carvalho, and Castro (2011) [4], an absorbent is considered to be economy-friendly if it is absolute in nature, a waste from an industry, and requires little processing.

Given the considerations and requirements, this study focused on the GAS shells as an absorber of heavy metals, specifically Lead $(\mathrm{Pb})$ from aqueous solutions. With the consideration of the rampant increase of a particular pest which is the GAS that mainly feeds on any succulent greens including the newly planted rice seedlings that can destroy farms, livelihood and be a burden to rice productions [14].

Although snails are considered pests and are looked upon as demise to farmers rather than an aid to their fields, snail shells are indeed made of mostly calcium carbonate. They also contain small amounts of protein. The shells consist of calcium carbonate crystals organized within a matrix of protein thus making GAS shells as an effective absorber [16].
Calcium carbonate $\left(\mathrm{CaCO}_{3}\right)$ is one of the most promising compounds that effectively absorb heavy metal pollutants found in waste-water treatment plants. It is alleged that shells can be an excellent chelating agent due to its calcium carbonate composition. The result of this study can suggest that cheap, environment-friendly and easy-processed catalyst can be apprehended using the GAS shells [12]. This study focused on the potentiality and bio-significance of powdered GAS shells as a chelating agent to effectively absorb lead $(\mathrm{Pb})$.

\section{Materials and Methods}

\subsection{Preparation of Chelating Agent}

Eight kilograms of fresh GAS shells of various sizes were collected from Tagabaca, Butuan City and were brought to the ASSAY Laboratory, Milling Department, PHILSAGA Laboratory, Rosario, Agusan del Sur. The shells were boiled in order to scrape free of its loose tissue, washed thoroughly and sun-dried to remove any inessential organic material including its unpleasant odor. It was then powdered using a clean blender and was later refined with the help of a Ring Mill. After pulverizing, the powdered GAS shells were then baked in a hot air oven at $110^{\circ} \mathrm{C}$ for 1 hour.

\subsection{Preparation of Solutions}

One thousand ppm of Standard Lead $(\mathrm{Pb})$ and $31 \mathrm{~L}$ beakers were prepared for the solutions. The $50 \mathrm{~mL}, 100 \mathrm{~mL}$, and $150 \mathrm{~mL}$ grams of lead $(\mathrm{Pb})$ were diluted in a three separate $1000 \mathrm{~mL}$ triple distilled water in three $1 \mathrm{~L}$ beakers in order to make a $50 \mathrm{ppm}, 100 \mathrm{ppm}$, and $150 \mathrm{ppm}$ solution. The three samples were given 6,12 and 18 hours of agitation and then were set aside for filtration ready for analysis.

\subsection{Flame Atomic Absorption Spectroscopy}

The samples were analyzed at PHILSAGA Mining Corporation Laboratory, Rosario, Agusan del Sur. The nine sample solutions that have undergone three trials with varying agitation time and were analyzed by the FLAAS to quantify what was left of the lead solution after the treatment of GAS shells, and also to identify whether greater agitation time will affect the absorption rate.

\section{Results and Discussion}

\subsection{Lead Absorption Capacity}

The concentration of heavy metal before the chelation process was at $51.02 \mathrm{ppm}, 101.01 \mathrm{ppm}$ and 151.36. However, after treating them with powdered GAS shells, the amount of lead $(\mathrm{Pb})$ present in water was greatly lessened. The average amount of lead $(\mathrm{Pb})$ content left in the solutions after treating them with powdered GAS was found to be at $0.03 \%$ leading to a conclusion that the average absorption of lead $(\mathrm{Pb})$ by GAS is $99.97 \%$. This amount of lead $(\mathrm{Pb})$ absorbed suggests that GAS shells can be a good and dispensable absorber. 
Moreover, varying concentrations ranging from 51.02-151.36 ppm before treatment shows the effectiveness of lead absorbency despite having different lead $(\mathrm{Pb})$ concentration results after treatment, they bear the same amount of lead $(\mathrm{Pb})$ residue and the difference is highly significant $(\mathrm{p}=0.003)$.

The efficacy of the absorptive capacity of GAS shells in regards to their heavy metal concentration can be related to the study of Ibigbami, Dawodu, \& Akinyeye (2014) [9], wherein their study shows that concentration of heavy metals create a significant effect on the absorption rate through increasing the ability of the surface functional groups of chitosan which is amino/acetamido group to bind metal ions and provide a driving force to overcome the mass transfer resistance of metal between the aqueous and solid phases. Although there is an increase in the number of metal ions bound, the percentage of heavy metal absorbed decreases. Their data shows a lead $(\mathrm{Pb})$ removal of $99.97 \%$ at $75 \mathrm{mg} / \mathrm{L}$ solution and then dropped at $87.74 \%$ at $100 \mathrm{mg} / \mathrm{L}$ solution.

Consequently, the study of Radaideh, Abdulgader, and Barjenbruch (2017) [15] shows that chitin and chitosan can remove heavy metal ions with high performance when applied at different concentrations ranged between 1 to 20 $\mathrm{mg} / \mathrm{L}$. In their study, it is observed how the adsorption of heavy metal decreases with increasing initial concentration. These can be explained on the basis that the increase in the numbers of ions are competing for the available binding spaces and also because of the lack of active sites on the absorbent at higher concentrations thus leaving more metal ions were left in the solution at higher levels of concentration. However, in this study, results show that despite different concentrations of 51.02, 101.01, and 151.36 ppm the solutions bore the same amount of lead absorbed at $99.97 \%$. Despite the opposing results, this study shows that varying concentration ranging from 51.02-151.36 ppm do not affect the efficacy of GAS shells to absorb lead $(\mathrm{Pb})$.
Table 1. Percentage of lead $(\mathrm{Pb})$ concentration absorbed and left from varying concentrated solutions after treating with powdered GAS shells in water.

\begin{tabular}{lll}
\hline $\begin{array}{l}\text { Concentration of Lead } \\
(\mathbf{P b}) \text { in water(ppm) }\end{array}$ & $\begin{array}{l}\text { Average Lead (Pb) } \\
\text { Absorbed }(\mathbf{p p m})\end{array}$ & $\begin{array}{l}\text { Average Lead } \\
\mathbf{( P b )} \text { Left (ppm) }\end{array}$ \\
\hline 51.02 & $51.00(99.97 \%)$ & $0.02(0.03 \%)$ \\
101.01 & $100.98(99.97 \%)$ & $0.03(0.03 \%)$ \\
151.36 & $151.31(99.97 \%)$ & $0.05(0.03 \%)$ \\
\hline
\end{tabular}

\subsection{Efficacy with Agitation Time}

The findings based on the Figure show a high percentage of absorbed lead $(\mathrm{Pb})$ concentration with a very little percentage left after the water samples were treated with GAS shells with increasing agitation time. Results show that samples bearing 6-12 hours of agitation time bear the same percentage of absorption which is $99.97 \%$. After 18 hours agitation time, the samples bear $99.96 \%$ absorption. It is shown that the longer the agitation time, the lesser percentage of lead will be absorbed.

Similar results from the study of Alyuz and Veli (2007) [20] determining the adsorption of copper $(\mathrm{Cu})$ and zinc $(\mathrm{Zn})$ using Cankiri bentonite (clay) is completed in relatively short increasing time period of 5-10 minutes. However, as their contact time increases at 80 minutes, the absorption decreases at $10 \mathrm{mg} / \mathrm{L}$ and completely stops at 150 minutes from the highest point of absorption of $20 \mathrm{mg} / \mathrm{L}$ at 5 minutes for Copper $(\mathrm{Cu})$ and 10 minutes for Zinc $(\mathrm{Zn})$. This similarity of results shows that greater contact time results in greater tendencies of lower absorption rates. Still, the difference of the data shown in this study does not create any significant change unto the ability of GAS shells to absorb lead $(\mathrm{Pb})$ with varying agitation time. Furthermore, the difference of lead concentration before and after treatment with varying agitation time is highly significant $(\mathrm{p}=0.003)$.

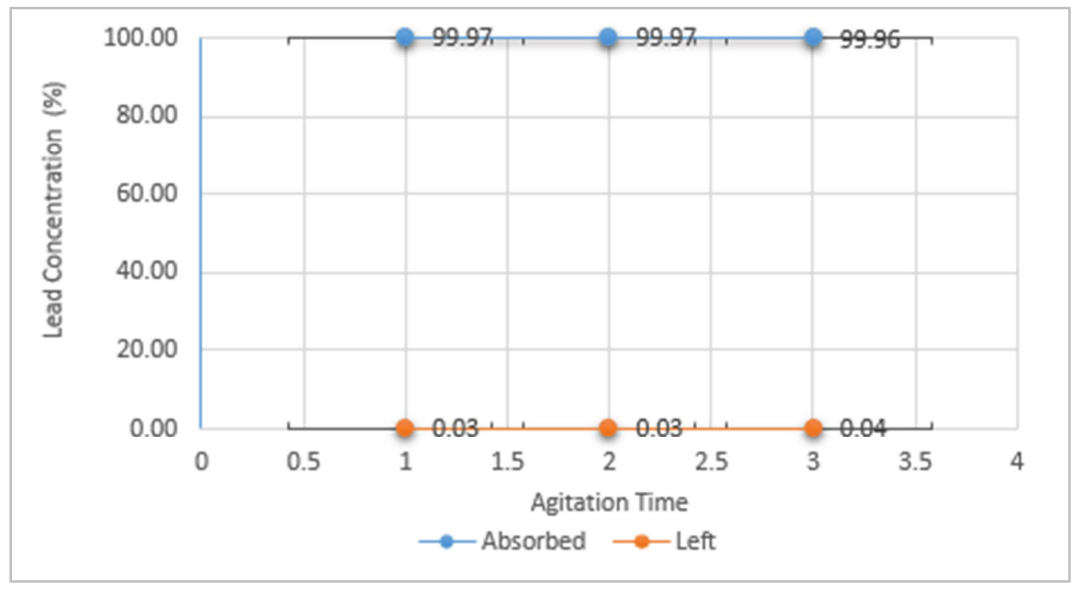

Figure 1. Percentage of lead $(P b)$ concentration after treating water with GAS shells based on agitation time.

\section{Conclusion}

Powdered GAS shells have a potential capacity to remediate lead-polluted bodies of water. With these data, inferences are made that there is only a specific range of the longevity of agitation that $20 \mathrm{~g}$ of treatment can absorb in any of the tested concentrations. Therefore, agitation affects the efficacy of the powdered GAS Shells as a chelating 
agent while the given range of concentration does not. Preliminary testing of the selected shells to a Fourier Transform Infrared Spectroscopy to determine the exposure of shells to any heavy metal contamination beforehand is suggested. Other species of snail may be selected as an absorbent and is encouraged to be compared to GAS. Furthermore, it is also encouraged to test the GAS shells' ability to absorb heavy metals like cadmium (Cd), mercury $(\mathrm{Hg})$, zinc $(\mathrm{Zn})$, Iron $(\mathrm{Fe})$ and heavy metals other than lead $(\mathrm{Pb})$ as well as to synthesize and characterize the chitin present in the shells.

This paper can contribute to an economic lift by making use of GAS shells as a new chelating agent which is costefficient. With this, it will create a major shift from presently expensive chelating agents to a cheaper heavy metal absorber biopolymer. It will then be utilized in cleaning wastewaters.

\section{References}

[1] Abadicio, C. (2017) Lopez inspects mining companies in CARAGA. Retrieved from http://cnnphilippines.com/news/2017/04/19/Lopez-inspectsmining-companies-in CARAGA.html.

[2] Akman, S., Baysal, A., \& Ozbek, N. (2013). Determination of trace metals in wastewater and their removal process. Retrieved from https://pdfs.semanticschol ar.org/f62a/ead3fe44673b94c04be54f4297d78836ebce.pdf.

[3] Amaya, D., Barragan, M., Tapia, J., \& Torres, G. (2015). Removal of heavy metals from aqueous solutions by aerobic and anaerobic biomass. Retrieved from https://cdn.intechopen.com/pdfs/49183.pdf.

[4] Araujo, D., Carvalho, T., \& Castro, A. (2011). Alternative low-cost adsorbent for water and wastewater decontamination derived from eggshell waste: an overview article. Retrieved from https://www.researchgate.net/publication/22731679 1_alternative lowcost_adsorbent_for_water_and_wastewater decontamination_derived_from_eggshell_waste_an_overview.

[5] Artiola, J., Brusseau, M., \& Famisan, G. (2004). Chemical contaminants. Retrieved from https://www.sciencedirect.com/science/article/pii/B978012064 4773500187.

[6] Darwish, L. (2015). Contaminants. Retrieved from earthrepair.ca/resources/contaminants/Department of Environment and Natural Resource (2018). Water resources. Retrieved

http://www.denr.gov.ph/index.php/component/content/article/ 19.html.

[7] Drioli, E., Islam, M., Figoli, A., Mozumder, M., \& Uddin, M. (2007). Arsenic removal by conventional and membrane technology: An overview. Retrieved from https://pdfs.sema nticscholar.org/3753/97d5dabfb5574ab5585969f540fda63c76 8f. pdf.
[8] Elofsson, K. (2010). The Costs of Meeting the Environmental Objectives for the Baltic Sea: A review of the literature. Retrieved from https://www.ncbi.nlm.nih.gov/pmc /articles/PMC2847692/.

[9] Ibigbami, T. B., Dawodu, F. A., \& Akinyeye, O. J. (2016, March 02). Removal of Heavy Metals from Pharmaceutical Industrial Wastewater Effluent by Combination of Adsorption and Chemical Precipitation Methods. Retrieved from http://www.sciencepublishinggroup.com/journal/paperinfo?jo urnalid=227\&doi=10.11648/j.ajac.20160401.15.

[10] Lavecchia, R. \& Zuorro, A. (2010). Adsorption of Pb (II) on spent leaves of green and black tea. Retrieved fromhttps://thescipub.com/pdf/10.3844/ajassp.2010.153.159.

[11] Lenntech, M. (2018). Lead (Pb). Retrieved from https://www.lenntech.com/periodic/ elements/pb.htm.

[12] Nordsieck, R. (2018). The Gastropod Shell - Part 1. Retrieved from http://www.mollus cs.at/gastropoda/index.html/gastropoda/morphology/shell.html.

[13] Patlolla, A., Tchounwou, P., Sutton, D., \& Yedjou, C. (2012). Heavy metals toxicity and the environment. Retrieved from https://www.ncbi.nlm.nih.gov/pmc/articles/PM C4144270/.

[14] Philippine Rice Research Institute (2001). Management options for the Golden Apple Snail. Retrieved from http://applesnail.net/pestalert/management_guide/pest_man agement.php.

[15] Radaideh J., Abulgader H., \& Barjenbruch M. (2017). Evaluation of absorption process of heavy metals removal found in pharmaceutical wastewater. J.Med Toxicol Clin Forensic Med, 3, 2, 9.

[16] Rae, R. (2017). The gastropod shell has been coopted to kill parasitic nematodes. Retrieved from https://core.ac.uk/download/pdf/84342063.pdf.

[17] United States Environmental Protection Agency (2017). Lead. Retrieved from https://www.epa.gov/lead/learn-about-lead.

[18] Wang, M. \& Wang L. (2016). Removal of heavy metal ions by poly (vinyl alcohol) and carboxymethyl cellulose composite hydrogels prepared by a freeze-thaw method. Retrieved from https://pubs.acs.org/doi/abs/10.1021/acssuschemeng.6b00336.

[19] World Health Organization (2018). Lead poisoning and health. Retrieved http://www.who.int/mediacentre/factsheets/fs379/en/.

[20] Veli, Sevil \& Alyüz, Bilge. (2007). Adsorption of copper and zinc from aqueous solutions by using natural clay. Journal of

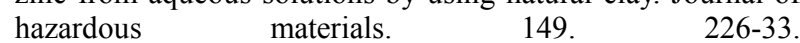
10.1016/j.jhazmat.2007.04.109.

[21] Anbalagan, N., Beeregowda, K., Jaishankar, M., Mathew, B., \& Tseten, T. (2014). Retrieved from https://www.ncbi.nlm.nih.gov/pmc/articles/PMC4427717/. 